PART 8. OTHER PAPERS 


\title{
MILESTONES OF INFORMATION EXCHANGE IN ASTRONOMY FROM PREHISTORY TO THE PRESENT
}

\author{
Magda Vargha Konkoly Observatory
}

\begin{abstract}
"That tho' a Man were admitted into Heaven to view the wonderful Fabrick of the World, and the Beauty of the Stars, yet what would be otherwise be Rapture and Extasie would be but a melancholy Amazement if he had not a Friend to communicate it to."
\end{abstract}

Attributed to Archytas by Christian Huygens

$\mathrm{Th}$ e $\mathrm{B}$ e $\mathrm{g} i \mathrm{n} \mathrm{n} i \mathrm{n} \mathrm{g}$. The origins of astronomy as a science can be traced back to the time when watchers of the sky first began to record the results of their observations and transmit them succeeding generations. The media used by these earliest astronomers were various, from great megalithic monuments like Stonehenge to the clay tablets of the Babylonian ephemerists and the papyrus rolls of the Egyptians.

Even in Antiquity such records were the foundation for the advance of astronomical knowledge. Thus the Chaldean Tables of the Babylonian had a great influence on the development of Greek astronomy. And in $130 \mathrm{~B} . \mathrm{C}$. Hipparchus discovered the precession of the equinoxes by comparing his own observations with those of Timocharis a century and a half earlier. Later even Copernicus himself used the results of Timocharis, Ptolemy, and al-Battani.

$\mathrm{P}$ e $\mathrm{r}$ s o n a $1 \quad \mathrm{C} \circ \mathrm{n} \mathrm{t}$ a $\mathrm{c} \mathrm{s}$. From earliest times personal contact between astronomers has been a vital channel for the communication of astronomical knowledge. Thus Thales of Miletus reputedly attended the school on Cos founded by Babylonian sage Berossus, and Pythagoras of Samos acquired much of his basic knowledge on his travels to Egypt and the East. In 1267 the Persian astronomer Jamal al Din visited his Chinese colleagues in Peking in connection with the compilation of the Ilkhani Tables.

C e n t e r s of $R$ e $s$ e a $r$ h. The exchange of information between astronomers is greatly facilitated by centers of research and repositories of learning. An early example is the House of Wisdom founded in Bagdad by the calif al Mam'un in the 9 th century. From the 13 th century onwards universities have played a similar role in Europe. The existence of Latin as an international language facilitated communication and made it possible for scholars to teach everywhere in Europe.

$\mathrm{C} \circ$ o p e $\mathrm{r}$ a $\mathrm{t} i \mathrm{v}$ e. $\quad \mathrm{V}$ e $\mathrm{n} \mathrm{t} \mathrm{u}$ e $\mathrm{s}$. Ambitious undertakings demand collective effort. Thus the terrestrial survey in China directed by Nankung Jueh and I-Hsing in 725 involved simultaneous observations carried out in nine different places. Later a truly international group 
of Moslem astronomers completed I1khani Tables in 1272, while a similar collective effort produced the Alfonsine Tables under the authority of Alphonso $\mathrm{X}$. of Castile in 1252 .

P r $i \mathrm{n} t$ i $n \mathrm{~g}$. The pace of development accelerated tremendously after the invention of movable type in the $15 \mathrm{th}$ century, making possible a much more vigorous circulation of information. Astronomers could now easily compare their results with those of their colleagues. The whole body of accumulated information became universally available. A celebrated example is the famous Historia Coelestis of Tycho Brahe. An important milestone was the publication of the first astronomical yearbook, the Connaissance des Temps, first published in 1679 and continuously published until the present.

o b s e r v a t o r y Public a $t i \circ n s$. The $18 \mathrm{th}$ century saw the development of every form of cooperative astronomical activity under the stimulus of brilliant astronomers with extraordinary organizing ability. One of these was the Hungarian-born astronomer Maximilian Hell of the Royal Observatory in Vienna. He published the first regular observatory publication, the Ephemerides Astronomicae, a special astronomical yearbook containing, besides the usual astronomical tables, articles, news, observations, letters, descriptions of instruments, etc. The Ephemerides Astronomicae and its successors were the first regularly circulating astronomical publications.

I $n t$ e $r$ a $t i o n$ a 1 C o o p e $r$ a $t i o n$. The first international project between modern nation-states was undertaken by French and English astronomers preparing for the return of Halley's Comet in 1758-59. Joseph Nicolas Delisle, who had close personal contact with Edmund Halley, played a leading role in the preparations. He also organized the first astronomical expedition, for observing the transit of Venus in 1761 and 1769.

C u r r e $t \quad B$ i b 1 i o g r a p h y. Another outstanding organizer of international cooperation was Jerome Lalande, who through his extensive correspondence influenced astronomical research throughout the whole Europe. To his credit is also the first publication of a current bibliography of astronomical literature.

Astronomers' $\mathrm{Me}$ e $\mathrm{t} i \mathrm{ng} \mathrm{s}$ and $\mathrm{P}$ e $\mathrm{r} i \mathrm{od} i \mathrm{c}$ a $1 \mathrm{~s}$. Franz Xaver von Zach organized the first astronomers' meeting in Gotha 1798. Two years later he organized a team of 24 astronomers to undertake a systematic search for the hypothetical planet between Mars and Jupiter. In the same year he published the first astronomical periodical, the Monathliche Correspondenz, which was soon followed by other journals.

Internationa 1 organ izat $i$ on s. In 1863 the Astronomische Gesellschaft was formed in Heidelberg. From its inception it had an international character. of the 23 original members, 16 came from abroad. The Central Bureau - a telegraph service - was established in Kiel 1882. It made possible instant dissemination of the newest discoveries. 
$R$ e $t$ r s pect $1 \mathrm{ve}$ B $1 \mathrm{~b} 110 \mathrm{~g}$ a $\mathrm{p} h \mathrm{y}$. The first retrospective astronomical bibliography was published in Brussels in 1887-1889 by J.C. Houzeau and A Lancaster. Ten years later the Astronomische Gesellschaft organized the regular publication of a current bibliography, the Astronomischer Jahresbericht .

$\mathrm{M} a \mathrm{p} s$ and $\mathrm{C}$ a $\mathrm{t}$ a $1 \circ \mathrm{g} \mathrm{s}$. Ever increasing cooperation and mutual assistance between observatories made possible increasingly ambitious catalogs and star charts, such as the AG Katalog, Potsdam Durchmusterung, Cape Photographic Durchmusterung, Carte de Ciel, etc.

The International A $8 \mathrm{t}$ r $\mathrm{n}$ o $\mathrm{m} i \mathrm{c}$ a 1 U $\mathrm{n} i$ o $\mathrm{n}$ (IAU). The growing volume and variety of international contacts and cooperation created a demand for an international organization of astronomers to coordinate this activity. The International Astronomica1 Union was founded in Brussels in 1919. Even in the difficult days of World War II the IAU Central Bureau continued to further the flow of information between astronomers.

$\mathrm{N} e \mathrm{w}$ f $\mathrm{rms}$ of $\mathrm{c} \circ \mathrm{op} \mathrm{r}$ a $\mathrm{t} i \mathrm{n}$. In the years after the War new forms of international cooperation developed. An example is the european journal Astronomy. and Astrophysics, edited and published by astronomers from several different countries. Observatories built and maintained by several nations in common are an even more conspicuous instance of the deepening spirit of internationalism.

Recent years have seen an explosive growth in the means of collecting, storing, and distributing astronomical information. Nevertheless, even as in Antiquity, personal contact and correspondence between astronomers remains one of the most important means of sharing the results of research and stimulating new endeavors. " 'Twould be but a melancholy amazement if had not a friend to communicate it to." 